\title{
Environmental Intervention as a Tool for Control of Schistosomiasis. Suggestions From a Field Study in Northeast Brazil
}

\author{
Controle da Esquistossomose Mediante Emprego de Medidas \\ Ambientais. Sugestões a partir de um Estudo de Campo no Nordeste \\ Brasileiro
}

\author{
Kurt Kloetzel ${ }^{1}$ \\ Pedro Paulo Chieffi ${ }^{2}$ \\ Flair José Carrilho ${ }^{3}$
}

KLOETZEL, K.; CHIEFFI, P.P. E CARRILHO, F. F. Environmental Intervention as a Tool for Control of Schistosomiasis. Suggestions From a Field Study in Northeast Brazil. Cad. Saúde Públ., Rio de Faneiro, 10 (supplement 2): 337-344, 1994.

The present survey from the State of Alagoas (Brazil) emphasized, once again, the importance of peridomestic or neighbourhood foci in the transmission of schistosomiasis mansoni. Although the study area consisted of a compact and densely populated urban community (Bairro Frio, União dos Palmares county), prevalence as well as the distribution of high egg counts was quite patchy, exhibiting a spatial pattern correlated with the distribution of ditches and other smallsized collections of surface water. Despite the availability of satisfactory water supply in most households, as well as the absence of any major body of water capable of furthering transmission, egg counts in Bairro Frio exceeded any other in our previous experience.

Morbidity, however, appeared to be insignificant, a trend which has been observed over the last decade in several other highly endemic areas. It appears clear to the authors that the control of transmission requires investment in environmental intervention and that this proposal, far from being utopic, can be furthered by quite modest means and through the participation of community or neighbourhood groups.

Key words:Schistosomiasis; Schistosoma mansoni; Control; Community Participation

\section{INTRODUCTION}

A striking spatial clustering of households with high egg counts and severe morbidity due to Schistosoma mansoni was

\footnotetext{
${ }^{1}$ Secretaria de Saúde e Higiene da Prefeitura do Muncípio de Santos. Praça Visconde de Mauá, s/n, Santos, SP, 11013-901, Brasil.

${ }^{2}$ Instituto de Medicina Tropical da Faculdade de Medicina da Universidade de São Paulo (LIM-06). Av. Dr. Enéas de Carvalho Aguiar, 470, São Paulo, SP, 05403-000, Brasil.

${ }^{3}$ Departamento de Gastroenterologia da Faculdade de Medicina da Universidade de São Paulo. Av. Dr. Enéas de Carvalho Aguiar, 251, $5^{\circ}$ andar, São Paulo, SP, 05403-000, Brasil.
}

demonstrated many years ago (Kloetzel, 1958; 1962) in an area of Northeastern Brazil, a finding which later led to a proposal of "selective chemotherapy" (Kloetzel, 1967) as a practical tool for the control of morbidity. Of late, when more generous funding allowed amplification of the project, it was demonstrated that the effects of chemotherapy did not last more than a short time, reinfection closely following (Kloetzel \& Vergetti, 1988).

In addition, the patterns of reinfection are found to be similar for the children of the same household, reproducing a spatial pattern almost identical to the clusters seen on primary infection (Kloetzel \& Schuster, 1987; 
Kloetzel \& Vergetti, 1988; Kloetzel et al., 1990). By plotting these findings on the map, detection of the responsible peridomiciliary focus can easily be achieved (Kloetzel \& Vergetti, 1988).

Clearly, "population-based" chemotherapy had not reduced to any extent the rate of transmission. We thus are forced to conclude that any reasonable degree of control demands a multidisciplinary approach, based upon chemotherapy plus intervention upon the environment (Barbosa \& Coimbra Jr., 1992). Evidence from the five areas hitherto investigated suggest that a selective policy, targeted towards areas at greatest risk will prove sufficiently effective (Kloetzel, 1967; Kloetzel \& Schuster, 1987; Kloetzel \& Vergetti, 1988; Kloetzel et al., 1990; Barbosa et al., 1993).

It so happens that environmental intervention (i.e., sanitary engineering) is usually dismissed as unrealistic, since held to be too costly for the developing countries. Such a view is based upon a too common fallacy, namely the belief that transmission of schistosomiasis is dependent on the presence of major bodies of polluted water as well as primitive conditions of domestic water supply.

\section{MATERIALS AND METHODS}

Bairro Frio is located in the tropical, humid coastal area of the State of Alagoas, at approximately 5.7 degrees W, 9.2 degrees $\mathrm{S}$. Densely populated, this can be considered an urban environment, an area of roughly 40 hectares ( 450 by 900 meters) comprising a population estimated at 12,000. Although belonging to União dos Palmares, Bairro Frio is a self-contained community, separated from the county seat by a $2 \mathrm{~km}$-wide plain (Figure $1)$.

FIGURE 1. Map of Bairro Frio, Suburb of the Municipality of União dos Palmares, State of Alagoas, Brazil

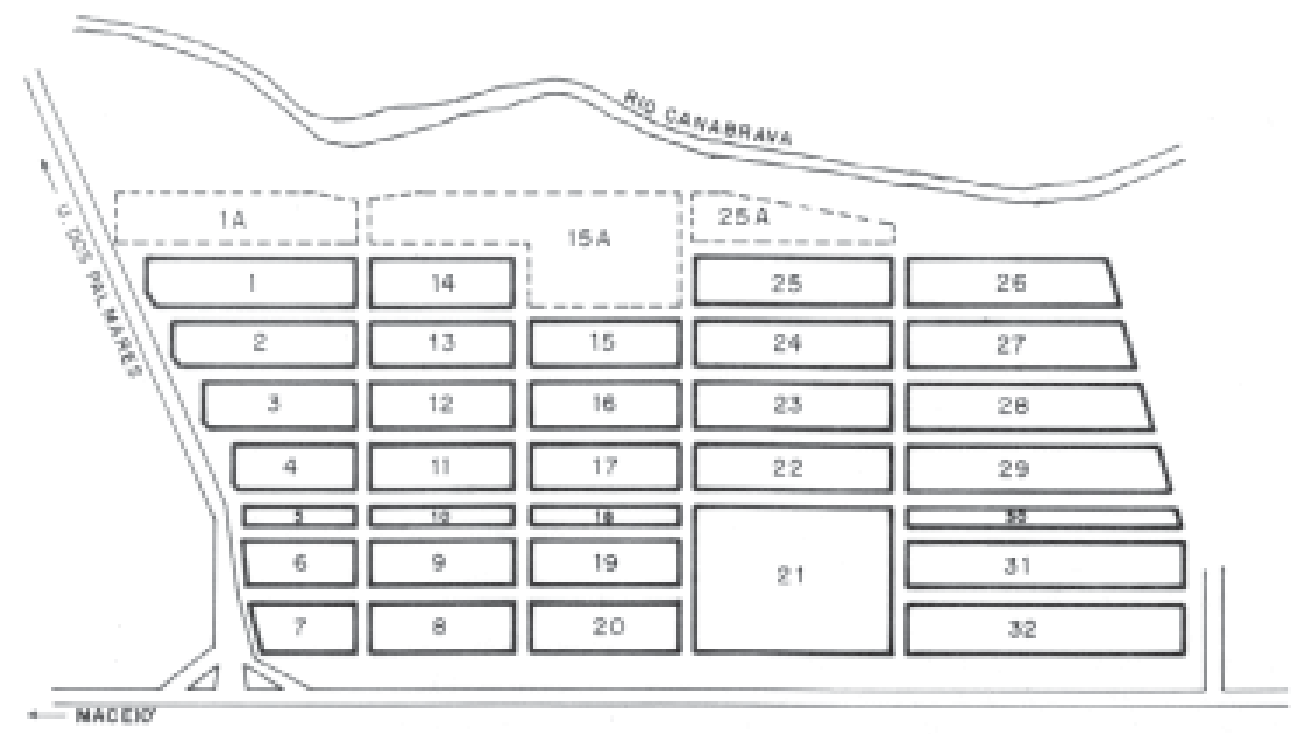


This plain is transversed by rio Canabrava, a modest, shallow creek scarcely three feet wide, unsuitable for bathing or recreation and not to be considered polluted. Once every two or three years, however, during the rainy season (August and September), it may rise above its banks, flood the surrounding plain and reach the doorsteps of the first lines of houses. While a rather steep slope leads from the highway down to the Canabrava, city blocks 1, 14, 25 and 26 are already on level ground.

While detailed information is still lacking, there is little doubt that this periodical flooding of outhouses and improvised toilets presents a major health hazard to the population. Throughout the entire year, however, Bairro Frio is exposed to yet another risk factor, namely drainage ditches and numerous puddles of water, to be found everywhere. Not only are these contaminated directly, mostly by small children, but very often collect the overflow from septic tanks or other types of toilet facilities.

Bad sanitation thus seems to be the main factor responsible for maintaining transmission. Conditions and availability of potable water does not appear to play a significant role, some $73 \%$ of the households having running water, the remainder either relying upon their neighbours or the public faucets distributed all over the settlement.
The present survey was carried out between June 1990 and September 1991. Coproscopic data are based upon the stool examination (Kato-Katz thick-smear technique) of 3,183 children between the ages of 2 and 14 - an estimated coverage of $93 \%$.

At the end of the survey, 155 subjects comprising those negative for $S$. mansoni as well as those with moderate and heavy egg counts were submitted to a physical examination and to ultrasonography of the abdomen according to a World Health Organization protocol (WHO, 1991). The ultrasonographical examination was carried out by means of a Yokogawa portable unit, provided with a $5 \mathrm{MHz}$ linear transductor.

\section{RESULTS}

Although the periodical mass-treatment campaigns in Bairro Frio were discontinued in 1986 , the intensity of infection is indeed startling (Table 1), considering that this is an urban area.

Bairro Frio exhibited the highest egg counts in all our experience, specimens showing more than 2,000 eggs per gram of feces (epg) not being unusual (Table 2). In fact, 27 of these subjects presented more than 2,500 epg.

TABLE 1.Prevalence and Intensity of Infection by Schistosoma mansoni in 3,183 children (2-14 years old) in Bairro Frio, União dos Palmares (AL), Brazil

\begin{tabular}{|c|c|c|c|c|}
\hline \multirow{2}{*}{$\begin{array}{l}\text { Age } \\
\text { (years) }\end{array}$} & \multirow{2}{*}{$\begin{array}{l}\text { Number } \\
\text { examined }\end{array}$} & \multirow[t]{2}{*}{ Prevalence $(\%)$} & \multicolumn{2}{|c|}{ Mean Counts (EPG) * } \\
\hline & & & Arithmetric & Geometric \\
\hline 2 & 252 & 3 & $<20$ & $<20$ \\
\hline 3 & 269 & 5 & 24 & 144 \\
\hline 4 & 220 & 18 & 24 & 240 \\
\hline 5 & 251 & 25 & 94 & 288 \\
\hline 6 & 227 & 40 & 84 & 257 \\
\hline 7 & 273 & 42 & 194 & 511 \\
\hline 8 & 251 & 47 & 240 & 634 \\
\hline 9 & 229 & 55 & 274 & 766 \\
\hline 10 & 255 & 62 & 298 & 763 \\
\hline 11 & 209 & 58 & 346 & 931 \\
\hline 12 & 276 & 74 & 374 & 987 \\
\hline 13 & 226 & 69 & 301 & 560 \\
\hline 14 & 217 & 64 & 295 & 650 \\
\hline
\end{tabular}

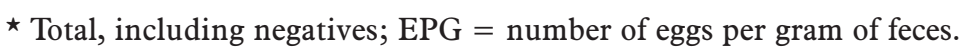


TABLE 2. Distribution of Intensity of Infection by Schistosoma mansoni in 3,183 children (2-14 years old) in Bairro Frio, União dos Palmares (AL), Brazil

\begin{tabular}{cc}
\hline \hline EPG $*$ & $\%$ of Total \\
\hline 0 & 51 \\
$1-100$ & 17 \\
$101-400$ & 16 \\
$>400$ & 16 \\
\hline \hline
\end{tabular}

$\star \mathrm{EPG}=$ number of eggs per gram of feces.

From the beginning it was observed that high egg counts were not randomly distributed throughout the area but aggregated within certain families in certain city blocks. This can be shown, although not as dramatically, in Table 3.
A correlation matrix was also drawn up (Table 4).

Abdominal ultrasonography was done not only on 129 individuals of the survey, 10 to 14 years of age, but also on 26 subjects in the $14-18$ years range. Subjects were distributed within three groups: Group A ( $\mathrm{n}=$ 38), negative Kato-Katz thick-smear; Group B $(\mathrm{n}=30)$, positive coprological tests -1 to 999 epg; Group C ( $\mathrm{n}=87)$, positive KatoKatz tick-smear -1,000 epg or over. Striking evidence of periportal fibrosis was not found in a single instance, in fact, for none of the nine parameters listed in the WHO protocol (WHO, 1991) were there statistically significant differences between the three groups (except for the finding of a rounded liver edge, more common in Group C).

In five of the subjects was the spleen palpable upon deep inspiration. On ultrasonography, four of these cases had a spleen length exceeding 120 milimeters.

TABLE 3. Prevalence and Intensity of Infection by Schistosoma mansoni Throughout Bairro Frio, União dos Palmares (AL), Brazil

\begin{tabular}{|c|c|c|}
\hline Block n" & Prevalence (\%) & Geom. mean (EPG) \\
\hline $1 \mathrm{~A}$ & 26 & 312 \\
\hline 1 & 27 & 360 \\
\hline 2 & 31 & 168 \\
\hline 3 & 22 & 144 \\
\hline 4 & 42 & 264 \\
\hline 5 & 20 & 192 \\
\hline 6 & 22 & 408 \\
\hline 7 & 41 & 432 \\
\hline 8 & 29 & 96 \\
\hline 9 & 41 & 240 \\
\hline 10 & 22 & 288 \\
\hline 11 & 28 & 312 \\
\hline 12 & 38 & 336 \\
\hline 13 & 42 & 552 \\
\hline 14 & 45 & 552 \\
\hline $15 \mathrm{~A}$ & 68 & 696 \\
\hline 15 & 82 & 912 \\
\hline 16 & 33 & 312 \\
\hline 17 & 26 & 240 \\
\hline 18 & 19 & 72 \\
\hline 19 & 44 & 312 \\
\hline 20 & 24 & 216 \\
\hline 21 & 62 & 462 \\
\hline 22 & 34 & 312 \\
\hline 23 & 42 & 360 \\
\hline 24 & 48 & 840 \\
\hline $25 \mathrm{~A}$ & 64 & 1368 \\
\hline 25 & 54 & 1128 \\
\hline 26 & 51 & 1224 \\
\hline 27 & 48 & 408 \\
\hline 28 & 44 & 432 \\
\hline 29 & 37 & 432 \\
\hline 30 & 48 & 432 \\
\hline 31 & 34 & 216 \\
\hline 32 & 42 & 312 \\
\hline
\end{tabular}


TABLE 4. Correlation Matrix of Data Relating Prevalence and Intensity of Infection by Schistosoma mansoni, Site of Dwelling and Age in Bairro Frio, União dos Palmares (AL), Brazil

\begin{tabular}{lcccc}
\hline \hline Correlations & Site \# & EPG & Age & Sex \\
\hline Site & 1.0000 & $0.1652^{*}$ & -0.0464 & -0.0390 \\
EPG & $0.1652^{*}$ & 1.0000 & 0.1063 & -0.0174 \\
Age & 0.0464 & $0.1063^{*}$ & 1.0000 & -0.0360 \\
Sex & -0.0390 & -0.0174 & -0.0360 & 1.0000 \\
\hline \hline
\end{tabular}

\# Distance of city block from lower left corner (Figure 1).

${ }^{\star} \mathrm{p}<0.001$

\section{DISCUSSION}

While the correlation matrix demonstrates a highly significant correlation between intensity of infection and age as well as intensity of infection and site of residence, multiple regression analysis reveals that no combination of factors "explains" more than a small proportion of the variability. This is not surprising: after all, in such a compact community it obviously is inappropriate to speak in terms of "peridomestic" rather than "neighbourhood" foci, and it can be predicted that highly mobile children simply cannot avoid contact with potential foci, in their immediate surroundings or elsewhere.

Since 1985, when the present series of studies in Alagoas began, we have been puzzled by the present benignity of the clinical picture displayed by schistosomiasis, a finding which was confirmed by other authors (Andrade \& Bina, 1985; Menezes-Neto, 1987). This pattern is in vivid contrast to the classical clinical description of hepatosplenic schistosomiasis, formerly so prevalent in many parts of Brazil (Meira, 1951). At present, new cases of hepatosplenic schistosomiasis are rarely to be found in Northeast Brazil, and when hospital records are examined the peak incidence in surgical cases of portal hypertension is found to be shifted from the 10-19-year age bracket to the 30-39-year group (Kloetzel \& Schuster, 1987; Coutinho \& Domingues, 1991).

In 1979, PECE (Programa Especial de
Controle da Esquistossomose), the national schistosomiasis control program, initiated a series of "mass treatment" campaigns throughout the State, initially with a periodicity of one year or so, depending on the county. Later on the program met with dificulties and had to resign itself to a spacing which in some cases was considerably longer. In addition, the non-participation rate during the first three courses of drug therapy can be estimated at $35 \%$, with a tendency for further increase.

Although the last mass treatment campaign in Bairro Frio took place in June, 1986, it is to be expected that a major proportion of the children over six years of age have received drug therapy at least once in their lives. Does this explain the absence of significant morbidity in our subjects?

Regression of hepatic lesions following chemotherapy has been reported repeatedly (Bina \& Prata, 1983; Andrade, 1989; Zwingenberger et al., 1990b; Coutinho \& Domingues, 1991; Mohamed-Ali et al., 1991), thus the answer might well be affirmative. Years ago the senior author himself postulated that chemotherapy would prove useful even in the presence of ongoing transmission, although predicting that in the event of massive reinfection the benefits of drug therapy would be insignificant (Kloetzel, 1963).

However, over the last few years conviction has grown that matters are more complicated than we originally thought. The 
causal link between a heavy worm burden and pathology, a traditional concept which the senior author himself proposed (Kloetzel, 1967), seems in need of reappraisal.

There are two equally plausible conjectures to be made, although there might be more. Thus there is a distinct possibility that we oversimplified the mechanisms leading to severe schistosomiasis mansoni, and that we are actually dealing with a multifactorial rather than unicausal process, with one or more as yet unknown co-factors (such as a concomitant infection by some other agent, or an as yet unrecognized nutritional deficiency) having in the meantime left the scene.

Recent reports by Zwingenberger et al. (1990a, 1990b) suggest a second, even more provocative hypothesis. By assessing the pathophysiological changes related to liver fibrosis and quantifying circulating T-cell subsets 18 months after treatment with praziquantel, they demonstrated that indicators for hepatic morbidity remained largely within normal values even in the presence of reinfection, while characteristic alterations concerning T-cells recurred promptly after reinfection. This led them to postulate " $a$ dissociation of factors regulating fibrogenesis and immunomodulation after treatment and reinfection" (Zwingenberger et al., 1999b: 457).

While based upon an admittedly modest population sample, these findings clearly deserve attention. Are we now allowed to speculate that a one-time course of chemotherapy - or even, perhaps, a subcurative dose - will effectively protect against schistosomal liver fibrosis, although not avoiding reinfection?

Be it as it may, schistosomiasis in Northeast Brazil probably has ceased to be a major health problem. Although we have no personal experience with Africa, the same conclusion may be applied to parts of that continent, as illustrated by Gryseels (1989: 134): "It could be argued that an analysis of the relevance of schistosomiasis for public health should have taken place before starting any control efforts at all".

At present this debate has become somewhat redundant, since a major proportion of the specialists, forced to admit that control of morbidity has somehow been attained but being commited to research and development of a vaccine, now raise the banner of control of transmission. Moreover, after decades of efforts towards placing schistosomiasis within a select group of prioritary health problems, it is rather later to simply deactivate control programs and projects.

But a viable as well as sensible alternative remains: as long as control of schistosomiasis cannot simply be left to chance, it behooves us to devise a strategy capable not only to bring about a reduction of the rate of transmission of schistosomiasis itself but involving substantial fringe benefits in terms of community health as such. Sanitation is such an alternative and its rewards are not confined to schistosomiasis alone but include a general improvement in the quality of life as well as control of other water-borne diseases.

A question presents itself: is this feasible? In addition to the present study, past data (Kloetzel \& Schuster, 1987; Kloetzel \& Vergetti, 1988; Kloetzel et al., 1990) demonstrate that environmental intervention in Northeast Brazil, as well as elsewhere (Barbosa et al., 1993), does not require major engineering projects nor a sophisticated water supply system, and that the bulk of transmission takes place within small, selfcontained and usually temporary collections of water, the answer has to be affirmative.

It is not particularly expensive to dig out the bed of the Canabrava river in order to prevent occasional flooding, recruit a body of volunteers so that septic tanks can periodically be pumped out, improve flow in ditches or level the streets so as to prevent collection of stagnant water. A program of integrated and well-coordinated efforts on the part of the local authorities, church or community groups may well bring about - and maintain — the desired results. We are convinced that such a strategy, combined with the judicious use of chemotherapy, represents our best choice. 


\section{RESUMO}

KLOETZEL, K; CHIEFFI, P. P. \& CARRILHO, F. J. Controle da

Esquistossomose Mediante Emprego de Medidas Ambientais. Sugestões a partir de um Estudo de Campo no Nordeste

Brasileiro. Cad. Saúde Públ., Rio de Janeiro, 10 (suplemento 2): 337-344, 1994.

O presente estudo, realizado no Estado de Alagoas, mais uma vez demonstrou o papel relevante dos focos peridomiciliares ou de vizinhança na transmissão da esquistossomose. Embora se trate de uma área urbana, compacta e densamente povoada (Bairro Frio, município de União dos Palmares), a distribuição tanto da prevalência como dos indivíduos com contagem de ovos elevada nas fezes obedeceu a nítido padrão espacial, altamente correlacionado com a distribuição de valetas de drenagem e outras pequenas coleções de água. Embora a maioria dos habitantes tenha acesso a água potável e, não obstante a ausência de coleções de água de algum vulto, capazes de manter a transmissão, a intensidade das contagens de ovos superou quaisquer dados anteriormente obtidos em outras áreas. Ainda assim, a morbidade mostrou-se inexpressiva, tendência já observada na última década em outras regiões hiperendêmicas. Os autores estão convencidos que o controle da transmissão requer esforços na sentido de melhorar as condições ambientais e que semelhante proposta é inteiramente viável, podendo ser concretizada com o emprego de recursos bastante modestos e contando com a participação da comunidade.

Palavras-Chave: Esquistossomose; Schistosoma mansoni; Controle; Participação da Comunidade

\section{REFERENCES}

ANDRADE, Z. A., 1989. Evolution and involution of hepatosplenic schistosomiasis. Memórias do Instituto Oswaldo Cruz, 84 (suppl. I): 58-65.

ANDRADE, Z. A. \& BINA, J. C., 1985. The changing pattern of pathology due to Schistosoma mansoni infection. Memórias do Instituto Oswaldo Cruz, 80: 363-366.
BARBOSA, F. S. \& COIMBRA Jr., C. E. A., 1992. Alternative approaches in schistosomiasis control. Memórias do Instituto Oswaldo Cruz, 87 (suppl. IV): 215-220.

BARBOSA, F. S.; CRUZ, O. J.; HOLLANDA, E.; SIQUEIRA, S. A. V.; CARVALHO, M. A. P.; GOMES, M. L. \& ALMEIDA, A. S., 1993. Modelo alternativo para o controle da esquistossomose. Estado atual do projeto no Estado do Espírito Santo, Brasil. Cadernos de Saúde Pública, 9: 85-89.

BINA, J. C. \& PRATA, A., 1983. Regressão da hepatosplenomegalia pela tratamento específico da esquistossomose. Revista da Sociedade Brasileira de Medicina Tropical, 16: 213-218.

COUTINHO, A. \& DOMINGUES, A. L. C., 1991. O tratamento específico no controle da morbidade. In: Tópicos em Gastroenterologia (L. P. Castro \& P. R. Savassi, eds.), Rio de Janeiro: MEDSI.

GRYSEELS, B., 1989. The relevance of schistosomiasis for public health. Tropical Medicine and Parasitology, 40: 134-142.

KLOETZEL, K., 1958. A síndrome hépato-esplênica na esquistossomose mansônica. Considerações sôbre a incidência familiar. Revista Brasileira de Medicina, 15: 112-118.

, 1962. Splenomegaly in schistosomiasis mansoni. American Fournal of Tropical Medicine and Hygiene, 11: 472-476.

1963. Sobre a conveniência da quimioterapia da esquistossomose em populações em contínuo contacto com os focos. Revista do Instituto de Medicina Tropical de São Paulo, 5: 106110.

, 1967. A suggestion for the prevention of severe clinical forms of schistosomiasis mansoni. Bulletin of the World Health Organization, 37: 686-687.

KLOETZEL, K.; CHIEFFI, P. P. \& SIQUEIRA, J. G. V., 1990. Repeated mass treatment of schistosomiasis mansoni: experience in hyperendemic areas of Brazil. III. Techniques for assessment and surveillance. Transactions of the Royal Society of Tropical Medicine and Hygiene, 84: 74-79.

KLOETZEL, K. \& VERGETTI, A. M. A., 1988. Repeated mass treatment of schistosomiasis mansoni: experience in hyperendemic areas of Brazil. II. Micro-level evaluation of results. Annals of Tropical Medicine and Parasitology, 82: 367376.

KLOETZEL, K. \& SCHUSTER, N. H., 1987. Repeated mass treatment of schistosomiasis mansoni: experience in hyperendemic areas of Brazil. 
I. Parasitological effects and morbidity. Transactions of the Royal Society of Tropical Medicine and Hygiene, 81: 365-370.

MEIRA, J. A., 1951. Esquistossomose Hépatoesplênica. Tese de Concurso para Catedrático de Clínica de Doenças Tropicais e Infectuosas, São Paulo: Faculdade de Medicina, Universidade de São Paulo.

MENEZES-NETO, A. G., 1987. Esplenectomia e derivação espleno-renal distal realizadas em Sergipe antes e após o Programa Especial de Controle da Esquistossomose (Pece). Revista da Sociedade Brasileira de Medicina Tropical, 20: 41-43.

MOHAMED-ALI, Q.; DOEHRING-SCHWERDTFEGER, E.; ABDEL-RAHIM, I. M.; SCHLAKE, J.; KARDORFF, R.; FRANKE, D.; KAISER, C.; ELSHEIKH, M.; ABDALLA, M.; SCHAFER, P. \& EHRICH, J. H. H., 1991. Ultrasonographical investigation of periportal fibrosis in children with Schistosoma mansoni infection: reversibility of morbidity seven months after treatment with praziquantel. American Fournal of Tropical Medicine and Hygiene, 44: 444-451.
WHO (World Health Organization), 1991. Meeting on Ultrasonography in Schistosomiasis. Proposal for a practical guide to the standardized use of ultrasound in the assessment of pathological changes. TDR/ SCH/ ULTRASOUND/ 91.3 CTD. (Mimeo.)

ZWINGENBERGER, K.; HARMS, G.; POGGENSEE, U.; STEINER, A.; MUELLER, O. \& FELDMEIER, H., 1990a. Reinfection in human schistosomiasis mansoni: a prospective field study 18 months after praziquantel therapy. Annals of Tropical Medicine and Parasitology, 84: 457-465.

ZWINGENBERGER, K.; RICHTER, J.; SIQUEIRA, J. G. V. \& FELDMEIER, H., 1990b. Praziquantel in the treatment of hepatosplenic schistosomiasis: biochemical disease markers indicate deceleration of fibrogenesis and diminution of portal flow obstruction. Transaction of the Royal Society of Tropical Medicine and Hygiene, 84: 252-256. 